\title{
Virolysin, a Virus-Induced Lysin: Its Appearance and Function in Phage-Infected Staphylococci
}

\author{
By DORIS J. RALSTON, BEATRICE BAER, MIRIAM LIEBERMAN \\ AND A. P. KRUEGER \\ Department of Bacteriology, University of California, Berkeley, California, U.S.A.
}

(Received 14, September 1960)

\begin{abstract}
SUMMARY
The formation and role of enzyme, virolysin, in Staphylococcus aureus $\mathbf{K}_{1}$ infected with phages $P_{1}$ and $P_{14}$ are described. Virolysin is a by-product of the metabolism of the cell which is actively producing phage, not of the normal cell. Virolysin is first detected within 10-15 min. in a 40-50 min. latent period and increases linearly until lysis. Normal cell autolysin remains constant during infection. Observations on lysis and phage release show that (1) certain inhibitors which prevent lysis of the cocci by external virolysin also prevent lysis and phage release when added at the end of the latent period; (2) the rate of premature lysis of, and phage release from, cocci chilled during the latent period depends upon their virolysin content. Both observations suggest that virolysin functions in phage release.
\end{abstract}

\section{INTRODUCTION}

Lysins obtained from phage-infected bacteria were reported by Bronfenbrenner \& Muckenfuss (1927) for a staphylococcal system, by Sertić (1929) for a coliphage system, and by Humphries (1948) for a klebsiella system. More recent publications describing phage-induced cell-wall or capsule-dissolving agents are those of Panijel \& Huppert (1954) for an Escherichia coli system, Ralston and collaborators (Ralston, Baer \& Krueger, $1955 a$; Ralston, Baer, Lieberman \& Krueger, 1955 $b$, 1957 $a$; Ralston, Lieberman, Baer \& Krueger, 1957b) for a Staphylococcus aureus system; and Adams \& Park (1956) for klebsiella, Murphy (1957) for Bacillus megaterium, Maxted (1957) for streptococci, Koch \& Dreyer (1958) for E. coli bacterium + bacteriophage systems. In addition to virus-induced lysins, other instances of virus-induced enzymes include DNA-synthesizing enzymes in $\boldsymbol{E}$. coli B-T phage systems (Kornberg, Zimmerman, Kornberg \& Josse, 1959; Flaks \& Cohen, 1959; Flaks, Lichtenstein \& Cohen, 1959), adenosine triphosphatase associated with avian myeloblastosis virus (Mommaerts et al. 1952) and the amidase of influenza virus (Gottschalk, 1952) in animal host + virus systems.

Virolysin is a lysin found in lysates of Staphylococcus aureus $\mathbf{K}_{1}$ infected with phage $\mathrm{P}_{1}$. In previous publications (Ralston et al., 1955 $a, b ; 1957 a, b$ ) we showed the following features : virolysin has the properties of an enzyme; it cannot be found in uninfected cocci but a similar enzyme, autolysin, is present. The two enzymes differ in their substrate specificity, antigenicity and $\mathrm{pH}$ optimum. For virolysin to act externally the cocci must be pretreated with phage, heat, acetone, urea or a 
variety of other damaging agents. We suggested that: (1) virolysin acts on a substrate forming the framework of the bacterial wall; $(2)$ in order for the substrate to become available to the enzyme, a preliminary alteration (presumably of the wall) must occur.

Preliminary studies (Ralston et al., 1955b) suggested that virolysin appeared intracellularly during phage infection and that it acted in the final lysis to release virus. The present work was undertaken to obtain further information about the relationship between phage infection, virolysin appearance and the role of virolysin in lysis. More specifically, it would be of interest to determine (1) when and how the enzyme appears in the infected coccus; (2) what effect phage infection has on the quantity of normal cell autolysin; (3) whether virolysin can be induced in the absence of phage or whether these syntheses are keyed one to the other; (4) whether phage release is dependent upon the presence and operation of the enzyme at the end of the latent period.

\section{METHODS}

Media. Tryptose phosphate broth or agar (Difco Labs., Detroit, Mich., U.S.A.) was used for growth of bacteria and studies on phage-infected cells. In this paper, the media are referred to as TP $1 \times$ or $2 \times$ broth (i.e. single or double strength broth) and TP agar.

Bacterium + bacteriophage systems and phage assay. The phages $\mathbf{P}_{\mathbf{1}}$ and $\mathbf{P}_{14}$ and their bacterial hosts Staphylococcus aureus, strains $\mathrm{K}_{1}$ and 145 , were described previously (Ralston \& Krueger, 1952, 1954). The method of assaying phage by a rapid plaque technique on the surface of microscope slides was previously reported (Jones \& Krueger, 1951; Ralston \& Baer, 1960). The following abbreviations are used throughout: $\mathrm{P}=$ phage; $\mathrm{C}=$ cocci $; \mathbf{P}_{14}\left(\mathrm{~K}_{1}\right)=$ phage 14 produced on strain $K_{1}$ cocci and $P_{1}(145)=$ phage 1 produced on strain 145 cocci, and so forth.

Preparation of lysins. To prepare autolysin, $1 \times 10^{8}$ resting uninfected $\mathrm{K}_{1} \mathrm{C} /$ ml. were shaken in TP $2 \times$ broth for $6 \mathrm{hr}$. at $37^{\circ}$ (final concentration $=3 \times 10^{9} \mathrm{C}$ / $\mathrm{ml}$.) and stored at $4^{\circ}$ until autolysis occurred (24-72 hr.). Preparation of virolysin $\mathrm{P}_{1}\left(\mathrm{~K}_{1}\right)$ involved shaking $1 \times 10^{8}$ resting $K_{1} \mathrm{C} / \mathrm{ml}$. with $1 \times 10^{6} \quad \mathrm{P}_{1}$ phage $/ \mathrm{ml}$. in TP $2 \times$ broth at $37^{\circ}$. Lysis of the culture occurred in $3 \mathrm{hr}$. The autolysates and lysates were spun at $20,000 \mathrm{~g}$ for $1 \mathrm{hr}$. at $6^{\circ}$. The $K_{1}$ autolysin and $P_{1}\left(K_{1}\right)$ virolysin were present in the supernatant fluids.

Determination of lysin activity. Virolysin and autolysin assays were performed by turbidimetric measurement of the lysis of heat-killed $K_{1}$ cocci under standardized conditions. The enzyme concentration in any particular sample of autolysin or virolysin was determined by mixing a suitable dilution of lysin with heat-killed $\mathbf{K}_{1}$ cocci at $37^{\circ}$ (sometimes, however, at $4^{\circ}$ ). Generally a $1 / 2$ to $1 / 100$ dilution of lysin in TP $2 \times$ broth at $\mathrm{pH} 7.5$ for virolysin, and $\mathrm{pH} 6.5$ for autolysin, was mixed with cocci so that the final volume in the tube was $5 \mathrm{ml}$. and the final concentration of cocci was $1 \times 10^{9} \mathrm{C} / \mathrm{ml}$. The decrease in turbidity was followed in a Klett-Summerson photoelectric colorimeter by taking readings at suitable intervals. From the data, the course of lysis can be represented by plotting the logarithm of the number of unlysed cocci against time at any given temperature. Only half of the heated cocci lysed and a correction was made for the resistant cocci in the population. A straight line was generally obtained (Ralston et al., 1957b). Estimates of 
lysin activity were based upon determinations of the initial velocity constants, $K / \mathrm{min}$., calculated from the equation:

$$
K=\frac{2 \cdot 3}{t} \log \frac{C_{0}}{C_{0}-C_{t}},
$$

in which $C_{0}$ equals the initial concentration of cocci/ml., $C_{t}$ equals cocci/ml. lysed in any given time interval, $t$. These relative velocity constants are reported only for purposes of comparison within an individual experiment. Less accurate estimates of lysin activity were made by determining the \% cocci lysed in a short time interval, and comparing the $\%$ lysis instead of the velocity constants, $K$, of individual samples.

Preparation of virolysin antiserum. A phage $\mathrm{P}_{1}\left(\mathrm{~K}_{1}\right)$ lysate was spun at $20,000 \mathrm{~g}$, for $1 \mathrm{hr}$. at $6^{\circ}$ in a Spinco Model $\mathrm{L}$ centrifuge. The pellet containing the phage was discarded. Solid $\left(\mathrm{NH}_{4}\right)_{2} \mathrm{SO}_{4}$ was added to the supernatant fluid at $0^{\circ}$ to $40 \%$ of saturation. The precipitated material was centrifuged at $4000 \mathrm{rev} . / \mathrm{min}$. for $15 \mathrm{~min}$. and resuspended in $0 \cdot 85 \%(\mathrm{w} / \mathrm{v}) \mathrm{NaCl}$. At least a tenfold concentration of the original activity was obtained. A rabbit was inoculated subcutaneously with progressively higher amounts $(\mathbf{0 . 5 - 2 \cdot 0} \mathrm{ml}$.) of the concentrated material in a series of sixteen injections over 3-4 weeks. Serum was collected 2 weeks after the last injection. A second rabbit was inoculated with autolysed cell contents, which exhibited no lysin action, to determine whether anything in the cell contents contained antigens similar to virolysin. A number of rabbit sera tested, including several phage antisera, contained a lysin for heated $\mathbf{K}_{\mathbf{1}}$ staphylococci. This lytic activity was not removed by heating the sera at $56^{\circ}$ for several hours, but was radically diminished by filtering the sera through Supercel filter-aid.

Antiserum inhibition tests. Antiserum to autolysin or virolysin was used at a dilution of 1/25 and mixed with enzyme for $20 \mathrm{~min}$. at $20^{\circ}$ before adding heat-killed bacteria. The enzyme control contained enzyme mixed with a similar dilution of normal rabbit serum.

Specificity of virolysin antiserum. From Tables 1 and 2 it is seen that: (1) antiserum to either $P_{1}$ or $P_{14}$ virolysins (produced on strain $K_{1}$ ) did not affect the normal $K_{1}$ cell autolysin, indicating that the virolysin was antigenically unrelated to autolysin; $(2)$ the antibody to $\mathbf{P}_{1}\left(\mathbf{K}_{1}\right)$ virolysin inactivated virolysin formed in either strain $K_{1}$ or strain 145 cocci, indicating that the antigenic specificity of the virus-induced enzyme depended on the phage rather than the host of production; (3) antiserum to the virolysin induced by the closely related phage $P_{14}$ also inactivated $P_{1}$ virolysin, regardless of the host, showing that the differences between the phages did not in-

Table 1. Staphylococcal virolysin. Effect of antiserum to $P_{1}\left(K_{1}\right)$ virolysin on $P_{1}\left(K_{1}\right)$ virolysin and staphylococcus strain $K_{1}$ autolysin

$\begin{array}{ll}\text { Virolysin + inactive autolysin } & 0 \cdot 026 \\ \text { Autolysin + inactive virolysin } & 0 \cdot 010 \\ \text { Autolysin + inactive virolysin + virolysin } & 0 \cdot 008 \\ \text { antiserum } & \\ \text { Virolysin + autolysin } & 0 \cdot 039 \\ \text { Virolysin + autolysin + virolysin } & 0 \cdot 010 \\ \text { antiserum } & \end{array}$


volve genes concerned with virolysin induction. $K_{1}$ autolysin antiserum is specific for autolysin and does not affect virolysin (Lieberman, 1956; Ralston et al., 1957b). The following controls gave no lysis of heated cocci: inactive virolysin +inactive autolysin; these two + virolysin antiserum; virolysin + inactive autolysin + virolysin antiserum. Inactive lysin was obtained by boiling a lysin sample for $5 \mathrm{~min}$.

Table 2. Staphylococcal virolysin. Effect of antiserum to $P_{14}\left(K_{1}\right)$ virolysin on $P_{14}\left(K_{1}\right), P_{1}\left(K_{1}\right)$, and $P_{14}(145)$ virolysins

\begin{tabular}{|c|c|c|c|}
\hline \multirow[b]{2}{*}{ Test mixture } & \multicolumn{3}{|c|}{ Virolysin from } \\
\hline & $\begin{array}{l}P_{14} \text { infection } \\
\text { of strain } K_{1}\end{array}$ & $\begin{array}{c}\mathbf{P}_{1} \text { infection } \\
\text { of strain } K_{1} \\
K / \text { min. at } 37^{\circ}\end{array}$ & $\begin{array}{l}P_{14} \text { infection } \\
\text { of strain } 145\end{array}$ \\
\hline $\begin{array}{l}\text { Enzyme } \\
\text { Enzyme + antiserum to } \\
P_{14}\left(K_{1}\right) \text { virolysin }\end{array}$ & $\begin{array}{l}0 \cdot 0204 \\
0.0000\end{array}$ & $\begin{array}{l}0.0530 \\
0.0000\end{array}$ & $\begin{array}{l}0.0154 \\
0.0000\end{array}$ \\
\hline
\end{tabular}

Analysis of total lysin, autolysin and virolysin content of phage-infected and uninfected cocci. Total lysin (virolysin + autolysin) in phage-infected cocci can be assayed on heated $\mathrm{K}_{1}$ cocci. The relative velocity constants, $K / \mathrm{min}$., of a mixture of the two has been shown to be equal to the sum of the activities of the individual lysins (Ralston et al., 1957 b). Autolysin in a mixture of the two lysins can be determined in three ways: (1) $\mathrm{K}$ autolysin $=\mathbf{K}_{\text {total lysin }}-\mathbf{K}_{\text {restdual lyoin }}$ in presence of autolysin antibody; or (2) $K_{\text {restdual lyain }}$ in presence of virolysin antibody; (3) by assay on acetone-treated Micrococcus lysodeikticus, which is lysed by autolysin but not by virolysin. Virolysin is determined by: $(a) \mathbf{K}$ virolysin $=\mathbf{K}_{\text {total lyein }}-\mathbf{K}_{\text {residual lysin }}$ in presence of virolysin antibody; $(b) \mathrm{K}_{\text {residual lyoin }}$ in presence of autolysin antibody.

\section{RESULTS}

Virolysin production in strain $K_{1}$ staphylococci during multiplication of phagel $P_{1}$

The following two experiments were designed to determine the appearance and increase of virolysin in the phage-infected cocci, to ascertain changes, if any, in the autolysin content of the cocci after infection, and to compare these with the appearance and increase of mature phage. The experiments differed from each other in the phage used and in the method used to obtain and assay the intracellular contents; the results of the two experiments corroborate each other.

Experiment 1. Staphylococci (strain $\mathrm{K}_{1}$ ), grown for $4 \mathrm{hr}$. at $37^{\circ}$, were suspended at $2.5 \times 10^{8} \mathrm{C} / \mathrm{ml}$. in TP broth, and infected with $P_{1}$ phage at a phage: coccus ratio of $4: 1$. The phage + cocci mixture was allowed to remain at room temperature for $3 \mathrm{~min}$. and then shaken at $37^{\circ}$. Samples were chilled at intervals and tyrothricin was added to $0.001 \mathrm{mg}$. $/ \mathrm{ml}$., to cause lysis (Fong \& Krueger, 1950); the concentration of tyrothricin used did not inactivate free phage or lysin. Lysin activities were determined by using virolysin antiserum and by assays on Micrococcus lysodeikticus.

Experiment 2. Staphylococci (strain $\mathrm{K}_{1}$ ) were grown on $\mathrm{TP}$ agar at $37^{\circ}$ for $4 \mathrm{hr}$., suspended in TP $2 \times$ broth to $2.5 \times 10^{8} \mathrm{C} / \mathrm{ml}$, , chilled to $4^{\circ}$, and infected with 
phage $14\left(K_{1}\right)$ at a phage: coccus ratio of $4: 1$. After 20 min. adsorption at $4^{\circ}$, the infected cocci were shaken at $37^{\circ}$ until lysed. Samples were removed at intervals, chilled to stop phage and enzyme development, and the cocci centrifuged down at low speed. To collect the intracellular materials, the chilled infected cocci were exposed to a lysing medium, composed of non-plaque-forming phage 14(145) (inactivated by ultraviolet irradiation) at about 10-20 particles/coccus and a $1 / 50$ dilution of 14(145) phage-free virolysin. The lysates were spun down at $4000 \mathrm{rev} . / \mathrm{min}$. and the supernatant fluids were analysed for phage and lysin content. Autolysin was distinguished from virolysin by the use of autolysin antiserum.

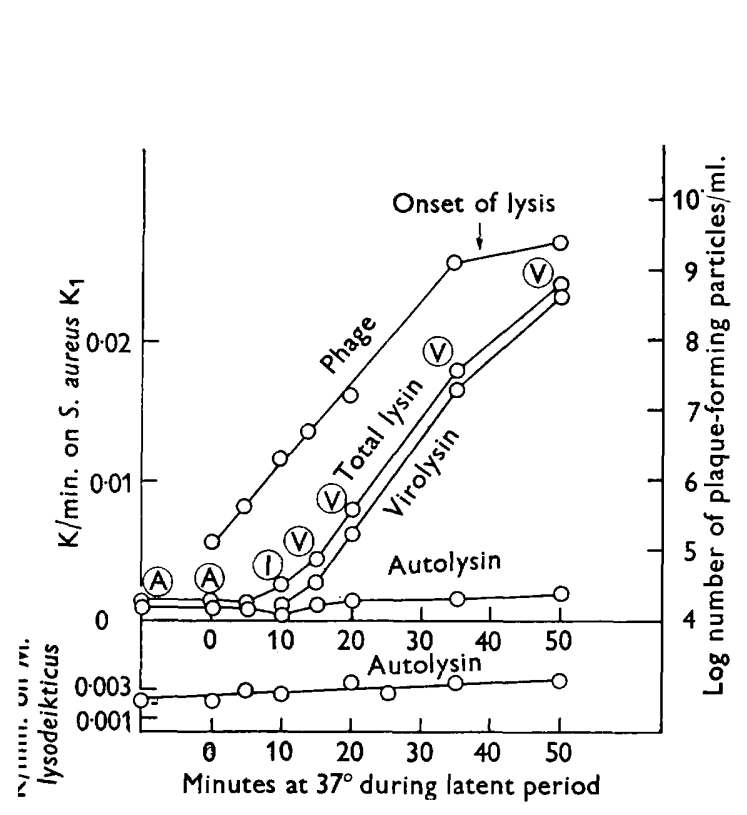

Fig. 1

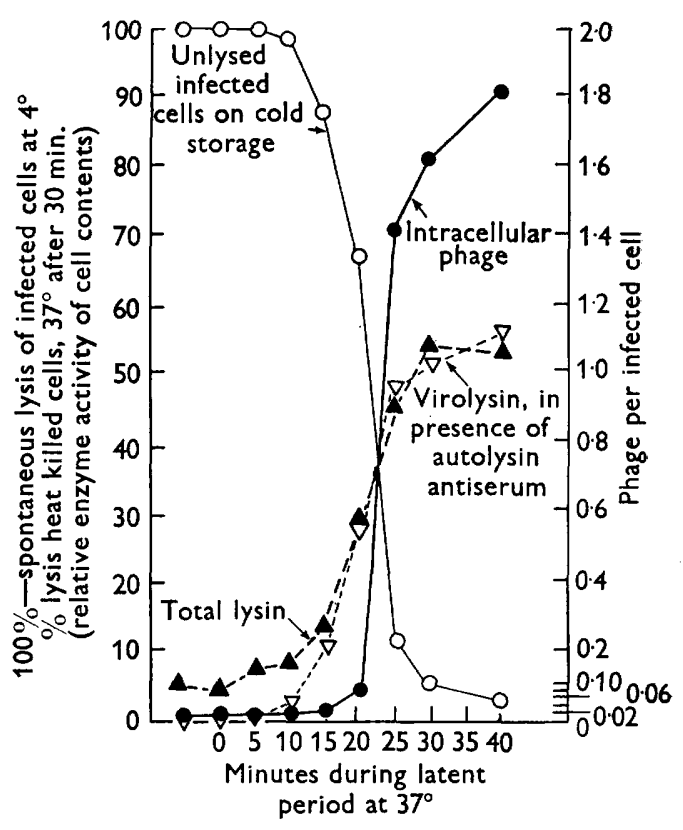

Fig. 2

Fig. 1. Formation of virolysin and phage during infection of staphylococcus strain $K_{1}$ organisms by phage $P_{1}$. The intracellular autolysin was determined from: (1) the total activity of the lysed coccal contents for Micrococcus lysodeikticus; (2) the residual activity of the lysates for strain $K_{1}$ cocci after exposure to virolysin antiserum. The circled letters, $A, I$ and $V$, above the values for the total lysin indicate that the pHoptimum of the sample was characteristic of autolysin (A), virolysin (V), or had an intermediate value (I). The phage was added at $0 \mathrm{~min}$.

Fig. 2. Formation of virolysin and phage during infection of strain $K_{1}$ cocei with phage $P_{14}$; spontaneous lysis of infected cocci on storage in the cold. The virolysin content was determined by the residual activity of the lysates for strain $K_{1}$ cocci after treatment with autolysin antiserum. The phage was added at $0 \mathrm{~min}$.

Lysin formation. Figures 1 (Expt. 1) and 2 (Expt. 2) show that a low value of lysin was present in uninfected cocci, and at 0-10 $\mathrm{min}$. in a 40-55 min. latent period at $37^{\circ}$. This lysin was identifiable as autolysin. The autolysin content of uninfected cocci remained essentially constant (in a few experiments it increased slightly, but never as much as twofold). Material identifiable as virolysin first appeared at 10-15 min., and then it increased essentially linearly until the end of the latent period. Figure 1 shows that during the latent period a change in the $\mathrm{pH}$ optimum 
of the total lysin occurred, from that for autolysin ( $\mathrm{pH} \mathrm{6.5)}$ to that for virolysin ( $\mathrm{pH} 7 \cdot 5)$.

Tests were made for possible intracellular inhibitors or activators of the enzymes. The lysed cell contents of samples of infected cocci removed at various times in the latent period were mixed with each other at final dilutions of $1 / 5$ in TP broth. Their activity indicated that under these conditions there was nothing present at any time which interfered with any lysin present, or which activated any unknown enzymes (Table 3, Expt. 1).

Table 3. Lack of enzyme inhibition or enhancment by mixtures of coccal contents during latent period of phage multiplication on lysin activity of individual samples

\begin{tabular}{|c|c|c|}
\hline $\begin{array}{c}\text { Individual samples } \\
\text { (time during latent period) }\end{array}$ & \multicolumn{2}{|c|}{ Enzyme activity* } \\
\hline Uninfected cocci & \multicolumn{2}{|c|}{$\mathbf{1}$} \\
\hline 0 min. infected cocci & \multicolumn{2}{|c|}{$\mathbf{1}$} \\
\hline 10 min. infected cocci & \multicolumn{2}{|c|}{$\mathbf{3}$} \\
\hline 20 min. infected cocci & \multicolumn{2}{|c|}{8} \\
\hline 35 min. infected cocci & \multicolumn{2}{|c|}{11} \\
\hline Phage lysate & \multicolumn{2}{|c|}{17} \\
\hline & \multicolumn{2}{|c|}{ Enzyme activity } \\
\hline Mixture of samples & Theoretical $\uparrow$ & Observed \\
\hline Uninfected cocci + lysate & 18 & 20 \\
\hline $0 \mathrm{~min} .+20 \mathrm{~min}$. & 9 & 9 \\
\hline 0 min. + lysate & 18 & 19 \\
\hline $10 \mathrm{~min} .+20 \mathrm{~min}$. & 11 & 11 \\
\hline 10 min. + lysate & 20 & 22 \\
\hline 20 min. + lysate & $\mathbf{2 5}$ & 27 \\
\hline $35 \mathrm{~min} .+$ lysate & 28 & 26 \\
\hline
\end{tabular}

$*$ Enzyme activity $=$ number of Klett units lysed after $48 \mathrm{hr}$. at $4^{\circ}$. Input in each tube was $9 \times 10^{8}$ heat-killed strain $K_{1}$ cocci (equivalent to $90 \mathrm{Klett}$ units) $/ \mathrm{ml}$. Each tube contained a $1 / 5$ dilution of samples; where a mixture was used, a 1/5 dilution of each lysin was present. Mixtures were allowed to remain at room temperature for several hours before assay cocci were added. Samples were additive.

$\dagger$ Sum of two individual samples calculated from above.

Relation between phage formation and enzyme synthesis. Analysis of the contents of cocci removed at intervals in the latent period indicated that the first mature particles appeared within $6 \mathrm{~min}$. and then increased logarithmically until shortly before mass lysis (Fig. 1). The first detectable virolysin generally appeared somewhat later and increased linearly (Fig. 1). The phage assay was much more sensitive than the virolysin assay. With the phage assay, one mature particle could be detected, provided that all free phage was removed after adsorption. We estimate that with the enzyme, under the present conditions of assay, approximately $5 \times 10^{6}$ to $1 \times 10^{7} \mathrm{C} / \mathrm{ml}$. must have formed enzyme maximally before its activity can be measured. The first detectable quantity of enzyme $/ \mathrm{ml}$. coincided roughly with the time at which $5 \times 10^{6}$ to $1 \times 10^{7} \mathrm{P} / \mathrm{ml}$. had appeared in the disrupted cell contents, suggesting that perhaps enzyme appearance is correlated with phage maturation. However, in the absence of knowledge about the distribution of enzyme and phage among individual cocci, this correlation may be more apparent than real. 
Absence of virolysin from abortive phage + coccus complexes and from uninfected cocci

While it is clear that virolysin is associated with active phage production, it would be of interest to ascertain whether it is produced by phage-adsorbed cocci which do not form virus, as well as by uninfected cocci grown and lysed under a variety of conditions.

Phage + coccus interactions. (I) Experiments with phage-sensitized cocci. It was found (Ralston et al., 1957a) that when enough phage particles were adsorbed, the cocci failed to form infective centres (plaques) on agar. They did not lyse by themselves when incubated in broth, but were lysed by externally added virolysin, in contrast to uninfected or phage-producing cocci. The lysates produced in this manner did not contain phage. Cocci in this condition have been called 'sensitized'.

The following experiment was designed to test whether virolysin production could occur in phage-sensitized cocci. Staphylococci of strain $K_{1}$, grown for $4 \mathrm{hr}$. on TP agar at $37^{\circ}$, were resuspended in TP $2 \times$ broth to $2 \cdot 0 \times 10^{8} \mathrm{C} / \mathrm{ml}$. and infected with phage $P_{14}\left(K_{1}\right)$ at phage: coccus ratios from 50 to 2 . (The addition of increasing amounts of phage to samples containing a constant number of cocci resulted in increasing numbers of sensitized cocci.) The numbers of infective centres were determined by removing samples at 20 min., treating with phage antiserum for 5 min., and then diluting for plaque count. The numbers of sensitized cocci were estimated from total phage-adsorbed cocci minus numbers of infective centres. The phage + coccus mixtures were incubated for $70 \mathrm{~min}$., by which time complete lysis had occurred in all tubes. The virolysin content of the tubes was determined by assay on heated $K_{1}$ staphylococci in presence of antiserum to normal cell autolysin. As shown in Table 4, the yield of virolysin was inversely proportional to the number of sensitized cocci, suggesting that these cocci did not form virolysin. It is presumed that their lysis was brought about by the action of external virolysin released from the cocci which had undergone active infection.

Table 4. Lack of staphylococcal virolysin production by phage-sensitized staphylococci

\begin{tabular}{|c|c|c|c|c|c|}
\hline $\begin{array}{l}\text { Phage input } \\
\text { per coccus }\end{array}$ & $\begin{array}{c}\text { Autolysin } \\
\text { and } \\
\text { virolysin } \\
\text { (total lysin) A }\end{array}$ & $\begin{array}{c}\text { Autolysin } \\
\text { (total lysin } \\
\text { and virolysin } \\
\text { antisera) B } \\
K / \text { min. value }\end{array}$ & $\begin{array}{c}\text { Virolysin } \\
\mathbf{A}-\mathbf{B}\end{array}$ & $\begin{array}{l}\text { No. of } \\
\text { cocci with } \\
\text { infective } \\
\text { centres* }\end{array}$ & $\begin{array}{c}\text { Relative } \\
\text { enzyme yiel } \\
\text { per infectiv } \\
\text { centre } \dagger\end{array}$ \\
\hline 50 & 0.0023 & 0.0012 & $0 \cdot 0011$ & $2 \times 10^{7}$ & 0.0012 \\
\hline 25 & $0 \cdot 0019$ & 0.0006 & 0.0013 & $2 \times 10^{7}$ & 0.0010 \\
\hline 10 & 0.0058 & $0 \cdot 0012$ & $0 \cdot 0046$ & $6 \times 10^{7}$ & 0.0010 \\
\hline $\mathbf{5}$ & $0 \cdot 0140$ & $0 \cdot 0035$ & $0 \cdot 0105$ & $1 \cdot 4 \times 10^{8}$ & 0.0010 \\
\hline 2 & 0.0170 & 0.0058 & 0.0112 & $1.2 \times 10^{8}$ & 0.0014 \\
\hline
\end{tabular}

The conclusion that no virolysin was formed in sensitized cocci is supported by other experiments in which cocci in the logarithmic growth phase were treated with large numbers of phage particles so that virtually the entire population was sensitized. The cocci were incubated at $37^{\circ}$ for twice the normal latent period, and 
at intervals samples were lysed-from-without by the addition of trace amounts of virolysin. The cell contents were then tested for lysin yield. Under these conditions, a constant amount of lysin was obtained from cocci lysed at each interval, and this was identified as normal cell autolysin.

(2) Experiments with host-altered phage. It was previously shown (Ralston \& Krueger, 1952,1954 ) that a host-controlled alteration occurred with phage $P_{14}$. Its host range was restricted after passage through staphylococci of strain 145 so that 34 out of 35 particles absorbed to and killed strain $K_{1}$ cocci, produced no phage and failed to cause lysis. The following experiment was carried out to test whether such cocci which did not produce phage formed virolysin (Fig. 3).

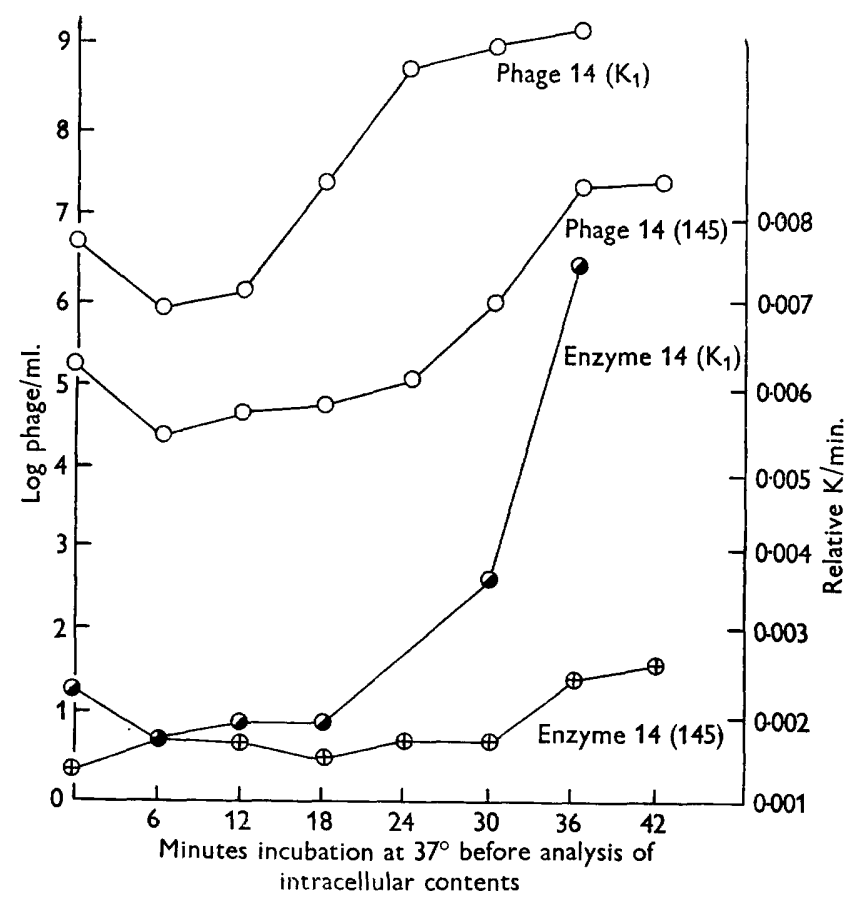

Fig. 3. Phage and enzyme formation by normal and host-altered phage $\mathbf{P}_{14}$.

Strain $K_{1}$ cocci were grown on TP agar at $37^{\circ}$, harvested after incubation for $3 \mathrm{hr}$. (logarithmic phase) and mixed with phage $P_{14}$, passed previously on host strain $K_{1}$ or strain 145 at $9 \times 10^{8} \mathrm{P} / \mathrm{ml}$. and $3.5 \times 10^{8} \mathrm{C} / \mathrm{ml}$. After $30 \mathrm{~min}$. at $4^{\circ}$ the temperature was raised to $37^{\circ}$. Samples were removed at intervals and chilled to stop infection. The intracellular contents were lysed-from-without at $4^{\circ}$ by suspending the cocci in samples of a lysing medium as described in Expt. 2. The tubes were then assayed for their relative amounts of phage and virolysin.

In contrast to infection of strain $K_{1}$ cocci with phage $14\left(K_{1}\right)$ the contents of cocci exposed to phage 14(145) (the restricted form) yielded low amounts of virolysin and phage. The low amount of enzyme formed by this infection mixture was accounted for on the basis of the 1 in 35 cocci which produced infective centres. We conclude, therefore, that the remainder of the cocci produced no enzyme. 
Attempts to find virolysin in uninfected cocci disrupted in different ways. We previously reported (Ralston et al. $1957 b$ ) that we were unable to detect virolysin in autolysates of strain $K_{1}$ cocci grown for $4 \mathrm{hr}$. and $24 \mathrm{hr}$. on TP agar and TP broth and autolysed by storage at $4^{\circ}$ or by incubation at $37^{\circ}$, under toluene. In the present work further efforts were made to detect virolysin in normal cocci by extending the range of conditions and ages under which uninfected strain $K_{1}$ cocci were grown and lysed. These included growth for 1 to $48 \mathrm{hr}$. on TP agar and TP broth at temperatures from $20^{\circ}$ to $37^{\circ}$ and at varying rates of shaking. The cultures, ranging from $1 \times 10^{8}$ to $4 \times 10^{9} \mathrm{C} / \mathrm{ml}$, were lysed in the following ways: (1) under toluene at $0^{\circ}$ and $20^{\circ}$; (2) by adding tyrothricin at $0^{\circ}-37^{\circ} ;(3)$ by storing cocci in shallow layers and in tall cylinders at $0^{\circ}-20^{\circ}$; (4) by disrupting cocci with glass beads; (5) by lysis-fromwithout by irradiated phage and a high dilution of virolysin; (6) by shaking slowly at $35^{\circ}$; this results in spontaneous lysis at $6 \mathrm{hr}$. (the late exponential phase of growth). Whenever a lysin was detectable in such lysates, it was identified as normal cell autolysin.

\section{Function of virolysin}

We have suggested that virolysin releases phage by acting on a substrate forming the framework of the cell wall (Ralston et al., 1955 b, 1957a). Isolated staphylococcal cell walls, prepared by disintegrating cocci with glass beads, or by trichloroacetic acid extraction and trypsin treatment (Hancock \& Park, 1958), are, in fact, dissolved by the action of the enzyme (data to be published). Further evidence to support the view that virolysin is an essential component of phage release is as follows.

Effect of inhibitors on lysis at the end of the latent period. Certain chemicals inhibit the action of external virolysin on phage- and heat-sensitized cocci (Ralston et al. $1957 a, b)$. Since there is a high concentration of virolysin in the coccus at the end of the latent period, these compounds should also inhibit the enzyme if it lyses the infected cocci-from-within (at least if the inhibitor penetrates the coccus). This was shown for $\mathrm{CuSO}_{4}$ (Ralston et al., 1955 b). In the present work, 22 other compounds, already tested for their action on external virolysin, were tested with infected cocci as follows. Strain $K_{1}$ cocci grown on $T P$ agar for $18 \mathrm{hr}$. were mixed with phage at a phage: coccus ratio of $3: 1$. Samples $(4 \mathrm{ml}$.) were dispensed into test tubes suitable for reading in a Klett colorimeter. The latent period was approximately $67 \mathrm{~min}$. Just before the $64 \mathrm{th}$ min., $1 \mathrm{ml}$. solution of substance to be tested as inhibitor was added to each tube. Readings were followed turbidimetrically for a further $50 \mathrm{~min}$. at $37^{\circ}$, and the tubes then placed at $4^{\circ}$ overnight. The amounts of lysis of infected cocci and of phage release were then determined. Table 5 shows that for each compound, with the exception of virolysin antibody, there was a good correlation between the inhibition of external virolysin and the inhibition of lysis of infected cocci and release of phage. In the case of virolysin antibodies, unlike the other inhibitors (low molecular weight compounds), it is presumed that the antiserum cannot pass across the cell wall or membrane.

Correlation betreen intracellular lysin content of infected cocci and their rate of spontaneous lysis. Cocci in which virus multiplication had been interrupted by chilling lysed spontaneously on storage at $4^{\circ}$. Figure 2 shows the amounts of lysis after $24 \mathrm{hr}$. of cocci chilled at intervals during the latent period. Cocci removed early lysed slowly, whereas those removed at later times lysed progressively faster. 
Table 5. Effect of enzyme inhibitors on lysis of phage-infected staphylococci and on phage yield

\begin{tabular}{|c|c|c|c|c|}
\hline Compounds & $\begin{array}{c}\text { Final } \\
\text { concentration } \\
\text { in TP broth }\end{array}$ & $\begin{array}{l}\text { Action on } \\
\text { extracellular } \\
\text { virolysin* }\end{array}$ & $\begin{array}{l}\% \text { lysis of } \\
\text { infected } \\
\text { cocci when } \\
\text { added at } \\
\text { end of } \\
\text { latent } \\
\text { period }\end{array}$ & $\begin{array}{r}\text { Yield of } \\
\text { virus } / \mathrm{ml}\end{array}$ \\
\hline Na citrate & $0.003 \mathrm{~g} . / \mathrm{ml}$. & None & 80 & N.t. \\
\hline $\mathrm{NaN}_{3}$ & $0.001 \mathrm{M}$ & None & 84 & N.t. \\
\hline $\mathrm{NaAsO}_{2}$ & $0.001 \mathrm{M}$ & None & 95 & $1 \times 10^{8}$ \\
\hline $\mathrm{NaF}$ & $0.001 \mathrm{M}$ & None & 83 & $4.5 \times 10^{8}$ \\
\hline Thiourea & $0.001 \mathrm{M}$ & None & 90 & $4.6 \times 10^{8}$ \\
\hline Semicarbazide & $0.001 \mathrm{M}$ & None & 80 & $4.3 \times 10^{8}$ \\
\hline K oxalate & $0.001 \mathrm{M}$ & None & 90 & N.t. \\
\hline Na sulphite & $0 \cdot 001 \mathrm{M}$ & None & 90 & N.t. \\
\hline KI & $0.001 \mathrm{M}$ & None & 87 & N.t. \\
\hline Na deoxycholate & $0.001 \mathrm{~g} . / \mathrm{ml}$. & None & 90 & N.t. \\
\hline Sulphanilic acid & $0.001 \mathrm{M}$ & None & 80 & $2.5 \times 10^{8}$ \\
\hline $\mathrm{PbCl}_{2} \dagger$ & $0.0004 \mathrm{M}$ & Variable & 26 & $1.2 \times 10^{8}$ \\
\hline $\mathrm{K}_{3} \mathrm{Fe}(\mathrm{CN})_{6} \dagger$ & $0.0033 \mathrm{M}$ & Variable & 60 & $1 \times 10^{7}$ \\
\hline Iodoacetic acid $\dagger$ & $0.001 \mathrm{M}$ & Variable & 80 & N.t. \\
\hline $\mathrm{HgCl}_{2}$ & $0.001 \mathrm{M}$ & Inhibitor & 0 & $1 \times 10^{4}$ \\
\hline $\mathrm{AgNO}_{3}$ & $0.001 \mathrm{M}$ & Inhibitor & $\mathbf{0}$ & $6 \times 10^{6}$ \\
\hline HCHO & $0.001 \mathrm{~g} . / \mathrm{ml}$ & Inhibitor & 0 & $1 \times 10^{2}$ \\
\hline Duponol & $0.001 \mathrm{~g} . / \mathrm{ml}$. & Inhibitor & 0 & $1 \times 10^{8}$ \\
\hline Thiomersalate & $0.001 \mathrm{M}$ & Inhibitor & 3 & $3 \times 10^{7}$ \\
\hline Hg acetate & $0.001 \mathrm{M}$ & Inhibitor & $\mathbf{0}$ & $8 \times 10^{3}$ \\
\hline$I_{2}$ in $K I$ & $\begin{array}{c}0.01 \mathrm{~N} \text { in } \\
0.25 \%(\mathrm{w} / \mathrm{v}) \mathrm{KI}\end{array}$ & Inhibitor & $\mathbf{0}$ & $1 \times 10^{1}$ \\
\hline Antibody to virolysin & $1 / 25$ dilution & Inhibitor & 80 & N.t. \\
\hline Control & - & - & 80 & $5 \times 10^{8}$ \\
\hline
\end{tabular}

* Results from Ralston et al. (1957b) effect of various compounds on lysis of heated or phagesensitized cocci by virolysin.

$\dagger$ In tests of the action of the soluble enzyme virolysin on heated cocci it was found that the degree of lysis in the presence of these compounds varied from experiment to experiment. One of the important factors appeared to be the age of the organisms used.

N.t. $=$ not tested.

The coccal contents of the early samples yielded no demonstrable virolysin and those of later samples contained increasingly greater concentrations of it. Although the lysis of early samples was accelerated by adding the lysing medium described in Expt. 2, or by the use of tyrothricin at $4^{\circ}$ or $37^{\circ}$, no increased amounts of enzyme could be recovered. These facts suggest that intracellular virolysin is not only responsible for the lysis of phage-infected cocci whenever the infection is prematurely interrupted, but also when it is allowed to proceed for the entire latent period.

\section{DISCUSSION}

Virolysin appearance in the infected coccus : new synthesis or unmasking of previously formed host enzyme? The available evidence points to the conclusion that the appearance of virolysin represents new enzyme formation following infection. This would follow if (1) the genes directing the synthesis of virolysin are inserted into the coccus 
at the time of virus penetration (if this proves to be the case, this system should be a favourable model for studying how genes direct protein synthesis); or (2) the phage introduces an inducer material for a repressed bacterial gene (Pardee, Jacob \& Monod, 1958).

Virolysin appearance does not seem to be an activation of a previously formed host enzyme, such as is the case with DNAase in the $\mathrm{T}_{2 r+}$ and $\mathrm{T}_{6 r+}$ infections of Escherichia coli B (Kunkee \& Pardee, 1956; Kosloff, 1953) for the following reasons: (1) DNAase appeared in uninfected organisms on storage, by adding a de-inhibitor, or by changing the $\mathrm{pH}$ value; no virolysin has been demonstrated by these devices. (2) Uninfected bacterial extracts in the $\mathrm{T}_{2 r+}$ system produced inhibition of the DNAase activity of lysates whereas, with our staphylococci, mixing uninfected extracts with samples at different times in the latent period produced no inhibition of virolysin activity. (3) The amount of activated DNAase in the uninfected organism was greater than that in the lysate at the end of the infection cycle; we found no virolysin in uninfected staphylococci but only a low concentration of autolysin which remained constant during infection. Also, there was no antigenic fraction in uninfected cocci which produced neutralizing antibody against virolysin.

$A$ general mechanism for the exit of viruses from host cells. Production of mucopolysaccharide-destroying enzymes may be a general mechanism evolved by viruses to accomplish their release from host cells; phage-induced lysins are known to exist in a taxonomically well-distributed number of bacterium + bacteriophage systems. In several instances it has been shown that they dissolve the bacterial cell wall which is known to contain a rigid framework of mucopolysaccharide. Similarly, the neuraminidase associated with the influenza particle may act to release the virus at the end of the growth cycle in animal cells (Gottschalk, 1958). Viral lysins may also act in penetration of the host cell by the virus particle (Adams \& Park, 1956). Since our phage does not cause lysis-from-without and since the virolysin is physically distinct from phage, there is no positive evidence in our system that the lysin acts to effect entrance of the virus into the host. Moreover, other experiments (to be published) indicate that the receptor material is distinct biochemically from the mucopolysaccharide affected by the virolysin. This would suggest that the entrance of phage DNA from one particle into the cell may be accomplished by an entirely different mechanism than the exit of numerous intact particles from the cell. On this basis one might expect the particles to contain a separate enzyme responsible for destruction of a non-rigid wall component (Murphy, 1960).

Factors other than virolysin which are essential to the lysis of phage-infected cocci. The staphylococcal cell wall is resistant to high internal concentrations of lysin as well as to externally added virolysin until the end of the latent period; this suggests that a sensitizing reaction is also necessary for internal virolysin to act. Perhaps sufficient phage particles on the inside can accomplish sensitization just as they do on the outside; however, the addition of large numbers of phage particles does not produce lysis. Both external virolysin and phage are required to lyse infected cocci. These preliminary observations suggest that both virolysin and phage are 'packaged' inside the cell and are prevented from carrying out their functions until an additional mechanism releases them. While virolysin appears to be a key lytic agent, this does not exclude autolysin; but since the latter is present in lesser concentrations, this may play a minor role. 
The work reported in this paper was supported by a grant from the Office of Naval Research and by NIH grants nos. E2379 and E 3776.

\section{REFERENCES}

Adams, M. H. \& Park, B. H. (1956). An enzyme produced by a phage-host cell system. II. The properties of the polysaccharide depolymerase. Virology, 2, 719.

Bronfenbrenner, J. \& Muckenfuss, R. (1927). Studies on the bacteriophage d'Herelle. VIII. The mechanism of lysis of dead bacteria in the presence of bacteriophage. J. exp. Med. 45, 887.

FLAKS, J. G. \& Cohen, S. S. (1959). Virus-induced acquisition of metabolic function. I. Enzymatic formation of 5-hydroxymethyldeoxycytidylate. J. biol. Chem. 234, 1501.

Flaks, J. G., Lichtenstein, J. \& Cohen, S. S. (1959). Virus-induced acquisition of metabolic function. II. Studies on the origin of the deoxycytidylate hydroxymethylase of bacteriophage-infected $E$. coli. J. biol. Chem. 234, 1507.

Fong, J. \& Krueger, A. P. (1950). The lytic action of tyrothricin and its derivatives on Staphylococcus aureus. J. gen. Physiol. 33, 311.

GotTsChalk, A. (1952). Carbohydrate residue of a urine mucoprotein inhibiting influenza virus haemagglutination. Nature, Lond. 170, 662.

GotTschalk, A. (1958). The prosthetic group of some mucoproteins and its relationship to influenza virus. In Chemistry and Biology of Mucopolysaccharides, p. 287. Ed. G. E. W. Wolstenholme \& M. O'Connor. Boston: Little, Brown and Co.

Hancock, R. \& Park, J. T. (1958). Cell-wall synthesis by Staphylococcus aureus in the presence of chloramphenicol. Nature, Lond. 181, 1050.

Humphries, J. C. (1948). Enzymic activity of bacteriophage-culture lysates. I. A capsule lysin active against Klebsiella pneumoniae type A. J. Bact. 56, 683.

Jones, D. \& Krueger, A. P. (1951). A rapid slide plaque technic for bacteriophage assay. J. gen. Physiol. 34, 347.

Koch, G. \& Dreyer, W. J. (1958). Characterization of an enzyme of phage $T_{2}$ as a lysozyme. Virology, 6, 291.

Kornberg, A., Zimmerman, S. B., Kornberg, S. R. \& Josse, J. (1959). Enzymatic synthesis of DNA. II. Influence of phage $\mathrm{T}_{2}$ on the synthetic pathway in host cells. Proc. nat. Acad. Sci., Wash. 45, 772.

Kosloff, L. M. (1953). Origin and fate of bacteriophage material. Cold Spr. Harb. Symp. quant. Biol. 18, 209.

Kunkee, R. E. \& Pardee, A. B. (1956). Studies on the role of desoxyribonuclease in $\mathbf{T}_{2}$ bacteriophage development. Biochim. biophys. Acta, 19, 236.

Lieberman, M. (1956). Aspects of lysis in normal and phage-infected staphylococci. Ph.D. Thesis, University of California, Berkeley.

MAXTED, W. R. (1957). The active agent in nascent phage lysis of streptococci. J. gen. Microbiol. 16, 584.

Mommaerts, E. B., Eckert, E. A., Beard, D., Sharp, D. G. \& Beard, J. W. (1952). Dephosphorylation of adenosine triphosphate by concentrates of the virus of avian erythromyeloblastic leucosis. Proc. Soc. exp. Biol., N.Y. 79, 450.

Murphy, J. S. (1957). A phage-associated enzyme of Bacillus megaterium which destroys the bacterial cell wall. Virology, 4, 563 .

Murphy, J. S. (1960). An agent derived from B. megaterium phage $\mathbf{G}$ which dissolves the bacterial cell wall. Virology, 11, 510.

PaniJel, J. \& Huppert, J. (1954). Mise en évidence et titration d'une substance lytique non reproductible en série (lysine) accompagnant la production d'un bactériophage. C.R. Acad. Sci., Paris, 238, 745.

Pardee, A. B., Jacob, F. \& Monod, J. (1958). Sur l'expression et le rôle des allèles 'inductible' et 'constitutive' dans la synthèse de la $\beta$-galactosidase des zygotes d'Escherichia coli. C.R. Acad. Sci., Paris, 246, 3125.

RAlston, D. J. \& BAER, B. (1960). Improved method of phage assay by a plaque count method on microscope slides in trays. J. Bact. 79, 758. 
Ralston, D. J. \& Krueger, A. P. (1952). Phage multiplication on two hosts. Isolation and activity of variants of staphylococcus phage $P_{1}$. Proc. Soc. exp. Biol., N.Y. 80, 217.

Ralston, D. J. \& Krueger, A. P. (1954). The isolation of a staphylococcal phage variant susceptible to an unusual host control. J. gen. Physiol. 37, 685.

Ralston, D. J., BaEr, B. \& Krueger, A. P. (1955a). Lytic factor found in staphylococcal bacteriophage lysates. Fed. Proc, 14, 475.

Ralston, D. J., Baer, B., Lieberman, M. \& Krueger, A. P. (1955b). Virolysin : a virusinduced lysin from staphylococcal phage lysates. Proc. Soc. exp. Biol., N.Y. 89, 502.

Ralston, D. J., Baer, B., Lieberman, M. \& Krueger, A. P. (1957 a). Lysis from without of $S$. aureus $\mathrm{K}_{1}$ by the combined action of phage and virolysin. J.gen. Physiol. 41, 343.

Ralston, D. J., Lieberman, M., Baer, B. \& Krueger, A. P. (1957b). Staphylococcal virolysin, a phage-induced lysin. Its differentiation from the autolysin of normal cells. J. gen. Physiol. 40, 791.

SERTić, V. (1929). Untersuchungen über einen Lysinzonen bildenden Bakteriophagen. I. Mitteilung: Der Aufbau der Bakteriophagenkolonien. Zbl. Bakt. (Abt. 1), 110, 125. 